\title{
In Vitro Immunotoxicity Testing of Pesticides using Human Cytokine Promoter Based Reporter Cell Lines
}

\author{
Dharamsheela Thakur ${ }^{1}$, Pankaj Singh ${ }^{1,2}$, Chakrapani Tripathi ${ }^{1}$, Smrati Bhadauria', Swatantra Kumar Jain ${ }^{2}$ and Raj Kamal Tripathi ${ }^{1 *}$
}

${ }^{1}$ Division of Toxicology, Central Drug Research Institute, Lucknow, India

${ }^{2}$ Department of Biotechnology, Jamia Hamdard University, New Delhi, India

\begin{abstract}
Pesticides including fungicides, herbicides and insecticides are the class of chemicals deliberately released into the environment because of their utility. Worldwide, an estimated, 3 million cases of pesticide exposure are reported per year. It has been established that pesticide chemicals can alter immune function and causes immunotoxicity. We have developed a model for immunotoxicity testing of chemicals in vitro by analyzing cytokine gene expression. The changes in cytokine gene expression observed in vitro was used as an endpoint for studying perturbation of the immune system in vivo. This system employs cell lines that have been transformed using constructs that have promoter region of Th1, Th2 cytokines and pro-inflammatory cytokines. These promoter regions regulate the expression of a reporter gene, Green Fluorescent Protein (GFP), and the activity of promoter to the external stimuli was compared with the expression of endogenous cytokine genes. CyclosporinA, FK506 (tacrolimus) and pentoxifylline, have been tested on this model and they showed specific pattern of suppression of reporter gene expression treated with PMA/ lonomycin and LPS. These immunosuppressants also suppressed the PMA/lonomycin and LPS induced endogenous gene expression of these cytokines. Thus our model has potential for application as a predictive screening test system for immunomodulatory activities of chemicals. The validation of the model was carried out using three pesticides chlorpyriphos, cypermethrin and captan that were known to have immunosuppressive activity on the expression of Th1 and Th2 cytokines. Following exposure to above pesticides, we also observed decrease in Th1 and Th2 cytokines promoter activity based GFP expression in our transformed cells line. Thus our model efficiently predicts the immunosuppressant nature of pesticides and therefore may serve as a tool for preliminary high throughput immunotoxicity screening of test agents such as pesticides and other environmental pollutants.
\end{abstract}

Keywords: Immunotoxicity; GFP; In vitro; T cells; RT PCR; Immunosuppressants; Pesticides

\section{Introduction}

Pesticides are the chemical substances used for preventing, destroying, repelling or mitigating any pest ranging from insects (i.e., insecticides), rodents (i.e., rodenticides) and weeds (herbicides) to microorganisms (i.e., algicides, fungicides or bactericides) [1]. Pesticides can be toxic to humans and lower animals based on concentration and mode of action [2-4]. Worldwide, an estimated three million cases of pesticide poisoning occur every year, resulting in an excess of 250000 deaths, primarily in developing countries [5]. Pesticides have been found to reduce the numbers of white blood cells and disease-fighting lymphocytes and impair the ability to respond against bacteria and viruses. Pesticides alter the function of the thymus and spleen, key immune organs. Methoxychlor and Endosulfan causesabberrant IgA and IgG production [6,7]. Pesticides associated immunomodulatory consequences may include immune enhancement, such as hypersensitivity and autoimmunity or immune suppression, which may increase the incidence of infectious disease or neoplastic transformation [8-10]. General toxicity of compounds could be assessed in vitro by evaluating degree and extent of test substance exposure induced cell death. However, immunotoxicity is quite difficult and it cannot be accomplished with a single test [1113]. Understanding the complexicity of immune system, multiple molecular and cellular targets of immunotoxicants have to be taken into account for immunotoxicity testing. The cytokines are the important components of immune system that connect disperse elements of the immune system. Since the dysregulation of cytokines gene expression explicitly represents the dysregulation of the immune system, it has become the valuable markers to study the alteration of immune system. Consequently, for immunotoxicity testing, i.e evaluating the toxic effects of chemical and pesticides on immune system, the analysis of cytokine gene expression has been widely employed [14-16].
The Propanil 3,4 dichloropropioanilide, a commonly used herbicides, to which agriculture workers were are frequently exposed, has been found to increase the plasma IgG1 levels and regulate IL-6, IL10 and IFN release. This was also associated with a reduced IFN/IL-4 ratio [17]. Studies conducted in children reveal that environmental toxicants induced adverse health effects are closely associated with altered Th1/Th2 cytokine profile $[18,19]$. The effect of chemical mixture of polychlorinated biphenyls (PCB), organochlorine pesticides (OCs) and methylmercury $(\mathrm{MeHg})$ was studied in children and results revealed that early exposures to these toxicants manifests itself as aberrant development of children's Th1/Th2 immune response. Studies conducted in rats reveal that perinatal exposure to environmental toxicants alters cytokine profile of rats [20]. Similarly amino acid derivative induce upregulation of IL-5 expression in lymphocytes in vivo [21] and chemokines in keratinocytes respectively $[20,21]$. Thus Assessment of cytokine expression could be a tool to evaluate chemical exposure effects on the immune system [22,23].

The cytokines gene expression could be efficiently measured by analyzing the promoter activity in response to external stimuli; therefore a reporter construct is made where the expression of reporter

*Corresponding author: Raj Kamal Tripathi, Scientist, Toxicology Division, Central Drug Research Institute (Council of Scientific \& Industrial Research) Lucknow-226001, India, Tel: 91-522-2612411; Fax: 91-522-2623405; E-mail rk_tripathi@cdri.res.in

Received February 20, 2013; Accepted March 23, 2013; Published March 26 2013

Citation: Thakur D, Singh P, Tripathi C, Bhadauria S, Jain SK, et al. (2013) In Vitro Immunotoxicity Testing of Pesticides using Human Cytokine Promoter Based Reporter Cell Lines. Clin Exp Pharmacol S4: 001. doi:10.4172/2161-1459.S4-001

Copyright: @ 2013 Thakur D, et al. This is an open-access article distributed under the terms of the Creative Commons Attribution License, which permits unrestricted use, distribution, and reproduction in any medium, provided the original author and source are credited. 
gene is regulated by cytokine cis- regulatory regions (promoters). Fluorescent proteins such as GFP (green fluorescent protein) as reporter genes allows for very efficient measure of translated reporter gene product in cell lines [24]. In present study, the GFP reporter constructs were made where reporter gene were regulated by Th1 and Th2 and inflammatory cytokine regulatory regions. The Th1 and Th2 regulatory region constructs were transfected in Jurkat $\mathrm{T}$ cell line and the inflammatory regulatory region was transfected in THP-1 cell line. The transformed cell lines reporter gene of Th1 (IL- 2 and IFN- $\gamma$ ) and Th2 (IL-4 and IL-10) were made to respond to the exposure of immunostimulant PMA (Phorbol Myristate Acetate)/Ionomycin and LPS (Lipopolysaccharide) and immuno suppressants like cyclosporine A (CsA) and FK506 on PMA/Ionomycin. Further, three pesticides; chlorpyriphos, cypermethrin and captan have been tested on this cytokine promoter based assay system so as to establish its applicability as a rapid and effective means to evaluate the pesticides/chemicals induced immunotoxicity.

\section{Materials and Methods}

\section{Construction of GFP reporter vectors}

To develop reporter cell lines for in vitro assay we constructed a set of reporter constructs, in which expression of GFP, was driven by regulatory sequences derived from the human IL-2, IFN- $\gamma$ (Interferon $\gamma$ ), IL-4, IL-10 and TNF- $\alpha$ genes. We made constructs of each cytokine promoters that included the main regulatory sites required for functional control of transcription. The IL-2 upstream region (-341 to +47$),$ IFN- $\gamma$ upstream region $(-565$ to +65$)$, IL-4 upstream region $(-582$ to +50$)$ upstream region $(-582$ to +50$)$, IL-10 upstream region $(-2087$ to +12$)$ and TNF- $\alpha$ upstream region $(-1131$ to +158$)$ relative to the transcription start site were amplified from human genomic DNA using the primers listed in table 1 . The PCR products were cloned into the pGlow Topo promoter less vector and sequenced for confirmation.

\section{Cell culture and stable transfection}

Jurkar T cells and THP-1 cells were obtained from in-house cell and tissue culture facility of Central Drug Research Institute. The Jurkat T and THP-1 cell lines were grown in RPMI 1640 complete media (20 $\mathrm{mM}$ L-Glutamine, $100 \mathrm{U} / \mathrm{ml}$ penicillin, $100 \mu \mathrm{g} / \mathrm{ml}$ streptomycin, and $10 \% \mathrm{FCS})$ at $37^{\circ} \mathrm{C}$ in $\mathrm{CO}_{2}$ incubator $\left(5 \% \mathrm{CO}_{2}\right)$. During transfection $4 \times 10^{6}$ Jurkat T and THP- 1 cells were suspended in incomplete culture medium (without FBS and antibiotics) mixed with $20 \mu \mathrm{g}$ plasmid DNA in a total volume of $0.4 \mathrm{ml}$, transfered to cuvette (4mm gap) and electroporated at $250 \mathrm{~V}$ (Jurkat T) and $300 \mathrm{~V}$ (THP-1) using the electroporator (BTX). After $2 \mathrm{hrs} 30 \mathrm{~min}$ of incubation in incomplete medium the cells were replenished with $20 \%$ FBS containing medium and incubated for $48 \mathrm{~h}$. The cells were selected with G418 (1mg/ml) by replacing medium with G418 every second day until the untransfected cells were dead. Limiting dilution cloning was performed and resulting single cell derived clones were expanded. The presence of the integrated reporter plasmids were verified by PCR for the EGFP coding region on genomic DNA from the clones using the following primer pair GFP fwd 5` ACT ACT GGA AAA CTA CCT GTT C 3’ GFP rev 5`ATA CGA TTA ACA AGG GTA TCA C $3{ }^{`}$ which binds to the GFP gene of the pGlowTopo vector.

\section{Cytotoxicity assessment of compounds}

Cytotoxicity of compounds on Jurkat T and THP-1 cell lines were analyzed by 3-(4,5-Dimethylthiazol-2-yl)-2,5-diphenyltetrazolium bromide (MTT) assay reflecting cell viability. For MTT assay $1 \times 10^{5}$ cells were treated with compounds at various concentrations. After $48 \mathrm{hrs}$ of seeding in 96 -well plate, $25 \mu \mathrm{l}$ of MTT solution $(2.5 \mathrm{mg} / \mathrm{ml})$ was added to each well and incubated for $4 \mathrm{hrs}$. Media was removed and $200 \mu \mathrm{l}$ DMSO was added to each well and incubated for $30 \mathrm{~min}$ at room temperature with shaking to dissolve the Formazon crystal completely. The optical density was measured in microplate reader (Biotek instruments, USA) at $570 \mathrm{~nm}$ and $690 \mathrm{~nm}$.

\section{Exposure to immunomodulators}

Transformed Jurkat $\mathrm{T}$ cell $\left(0.5 \times 10^{6}\right.$ cells $\left./ \mathrm{ml}\right)$ activated with or without PMA (20ng/ml Sigma) and Ionomycin $(1 \mu \mathrm{M}$, Sigma) were exposed to different immunosuppressive chemicals viz. cyclosporine A (CsA), Tacrolimus and FK506 for 48 h. Differentiated THP-1 cells activated with or without LPS $(1 \mu \mathrm{g} / \mathrm{ml})$ were treated with different chemicals for $48 \mathrm{hrs}$. After incubation cells were harvested and washed twice with pre-chilled PBS and then lysed in 1X Passive Lysis Buffer $(100 \mu \mathrm{l})$ by keeping cells on ice for $10 \mathrm{mins}$ with intermittent vortexing. After centrifugation at $13000 \mathrm{rpm}$ for 10mins, supernatant was collectedprotein concentration was estimated. For normalization, an aliquot containing total $100 \mu \mathrm{g}$ protein was transferred to dark colored 96 well of plates (Costar) and fluorescence intensity was recorded at excitation $395 \mathrm{~nm}$ and detection $520 \mathrm{~nm}$ in fluorimeter (Omega) which in turn served as a measure of GFP expression

\section{RT-PCR and Real-Time PCR analysis}

Control and treated cells were harvested and washed with PBS twice. Total RNA was isolated from $5 \times 10^{6}$ fresh cells using Pure link RNA extraction kit (Invitrogen) The RNA yield was quantified by UV spectrophotometer (Powerwave XS Biotek Germany) by recording absorbance at 260/280 and 260/230. Further purity/integrity check was performed by subjecting one microgram of total RNA to electrophoresis through $1 \%$ formamide agarose gels. Preservation of $28 \mathrm{~S}$ and 18 s rRNA was used to assess RNA integrity. RNA Samples without detection of 28S/18S RNA were excluded from the further examination. RNA was treated with DNAse (2unit/10 ug of RNA) to degrade the residual genomic DNA. cDNA was synthesized from $2 \mu \mathrm{g}$ of total RNA using SuperScript III One-Step RT-PCR System with Platinum Taq (Invitrogen). The one-step format enables easy

\begin{tabular}{|c|c|c|}
\hline Cytokines & Primer Sequence( $\left.5^{`} . \ldots \ldots . . .3^{`}\right)$ & Region amplified \\
\hline IL-2 & $\begin{array}{l}\text { Forward primer 5'TAT GAC AAA GAA AAT TTT CTG AGT TAC 3`' } \\
\text { Reverse primer 5'TGT GGC AGG AGT TGA GGT TAC TGT GAG 3`. }\end{array}$ & -341 to +47 \\
\hline IFN-Y & $\begin{array}{l}\text { Forward primer } 55^{\circ} \text { GTA TTT CTA CTG GGC AGT GCT GAT CTA G } 3^{\prime} \\
\text { Forward primer } 5{ }^{\circ} \text { GGT CCA AAG GAC TTA ACT GAT CTT TCT C } 3^{\prime}\end{array}$ & -565 to +65 \\
\hline IL-4 & $\begin{array}{l}\text { Forward primer } 5^{\circ} \text { GGC CTC ACC TGA TAC GAC CTG TCC TTC T } 3^{\circ} \\
\text { Forward primer } 5{ }^{\circ} \text { TTG CAG TGA CAA TGT GAG GCA ATT AGT T } 3^{\prime}\end{array}$ & -582 to +50 \\
\hline IL-10 & $\begin{array}{c}\text { Forward primer } 5^{\prime} \text { ATG CTG AGT CCA CTT CTG GAA CAC CCA GCT3 }^{\prime} \\
\text { Forward primer } 5^{\circ} \text { GCC TTC TTT TGC AAG TCT GTC TTG TG } 3^{\prime}\end{array}$ & -2087 to +12 \\
\hline TNF- $\alpha$ & $\begin{array}{l}\text { Forward primer } 5{ }^{\circ} \text { AGG GCT CAG AGA GCT TCA GGG ATA TGT GAT G 3`' } \\
\text { Forward primer } 5{ }^{\circ} \text { CAG GGG AGA GAG GGT GGA GCC GTG GGT CAG 3` }\end{array}$ & -1131 to +158 \\
\hline
\end{tabular}

Table 1: Regulatory region of cytokines used for study and primer sequence used for amplification of these regions. 
Citation: Thakur D, Singh P, Tripathi C, Bhadauria S, Jain SK, et al. (2013) In Vitro Immunotoxicity Testing of Pesticides using Human Cytokine Promoter Based Reporter Cell Lines. Clin Exp Pharmacol S4: 001. doi:10.4172/2161-1459.S4-001

Page 3 of 12

analysis of gene expression or detection of RNA. The cDNA and primer efficiency was confirmed by PCR amplification using Taq polymerase with pairs of primers as (Table 2). Quantitative real time PCR analysis was carried out in using same primers $(0.5 \mathrm{pM} /$ reaction $)$ (Table 2). Quantitiative PCR was performed on a Light Cycler 480 System (Roche) with cDNA (25ng/reaction) and duplicate primers (0.5pM/reaction) (Table 2) in 96-well plates using SYBR Green qPCR Master Mix (Invitrogen) in accordance with manufacturer's protocol. Data were analyzed using the Roche LightCycler 480 software (Version 1.5). Relative quantification of cDNA was done using $\delta \mathrm{CT}$ method. The amount of the target mRNA was examined and normalized to the $\beta$-actin gene mRNA/GAPDH gene mRNA. Results represent data from three separate experiments.

\section{Statistical analysis}

Data represents Mean \pm SE of 3 independent experiments wherein individual experiments contained three replica sets. Statistical analyses were performed using Graph pad prism 5 software package. The differences between classes were determined by one-way ANOVA followed by Bonferroni's $t$ test. $P<0.05$ were considered significant.

\section{Results}

\section{Effect of immunosuppressants on expression of reporter and endogenous cytokines gene}

The reporter cell lines were tested for their response to different known immunosuppressive compounds. Reporter cell lines were treated with immunosuppressors (cylosporinA, CsA and Tacrolimus, FK506) and pentoxifylline in the presence of specific stimulators of cytokine expression and the effect was assessed by analyzing both GFP reporter and endogenous cytokine gene expression. We determined the IC-10 concentration (concentration that caused $10 \%$ toxicity), for all the test agents viz CsA $(10 \mu \mathrm{g} / \mathrm{ml})$ FK506 $(8 \mu \mathrm{g} / \mathrm{ml})$ and pentoxifylline $(27.8$ $\mu \mathrm{g} / \mathrm{ml}$ ) (data not shown). Based on this, the studies were conducted on the proposed model system at IC-10 dosage/concentration and two subsequent dilutions of IC-10 viz IC-10/10 and IC-10/100.

PMA/Ionomycin induced GFP expression in IL-2, IFN- $\gamma$, IL-4 and IL-10 reporter jurkat $\mathrm{T}$ cell lines was significantly inhibited when activated cells were treated with cyclosporine A (CsA) at all the tested concentrations (Figure 1A) whereas the inhibition was inevident in LPS stimulated, TNF- $\alpha$ reporter THP-1 cells (Figure 1B). It also inhibited the PMA/Ionomycin IL-2, IFN- $\gamma$, IL-4 and IL-10 mRNA expression of endogenous cytokine genes in the reporter cell lines (Figure 1C) whereas the inhibitory effect was in evident in case of TNF- $\alpha$ mRNA expression in LPS activated THP-1 cell line(Figure 1D).

Another immunosuppressant FK506, significantly inhibited the PMA/Ionomycin induced GFP expression in IL-2, IFN- $\gamma$, IL-4 and IL-10 reporter jurkat $\mathrm{T}$ cell lines (Figure $2 \mathrm{~A}$ ) at all the tested concentrations whereas no inhibitory effect was observed in LPS stimulated, TNF- $\alpha$ reporter THP- 1 cells (Figure 2B). PMA/ Ionomycin induced endogenous IL-2, IFN- $\gamma$, IL-4 and IL-10 mRNA expression was also found to be inhibited upon treatment with this compound (Figure 2C) whereas it failed to alter TNF- $\alpha$ mRNA expression in LPS induced THP-1 cells (Figure 2D).

Pentoxifylline did not alter the PMA/Ionomycin induced upregulation of GFP mediated fluorescence in IL-2, IFN- $\gamma$, IL- 4 and IL10 reporter jurkat $\mathrm{T}$ cell lines (Figure $3 \mathrm{~A}$ ), whereas it inhibited the LPS induced GFP expression in TNF- $\alpha$ reporter THP-1 cells at all the doses in a characteristic dose dependent manner (Figure 3B). Pentoxifylline showed no effect on endogenous mRNA expression of IL-2, IFN gamma, IL-4 and IL-10 in PMA/Ionomycin activated Jurkat T cells and showed inhibitory effect on TNF- $\alpha$ reporter gene and endogenous TNF- $\alpha$ mRNA expression in LPS activated THP-1 cells (Figures $3 \mathrm{C}$ and $3 \mathrm{D})$.

These results demonstrated that CsA and FK-506 specifically targeted endogenous cytokine genes in jurkat $\mathrm{T}$ cells and these were able to regulate GFP reporter genes that were under the transcription control of cytokine regulatory regions. The specificity of regulating reporter genes was shown by pentoxyfylline which is TNF- $\alpha$ activator (Table 3).

\section{Effect of pesticides on expression of reporter and endogenous cytokine genes}

The Reporter cell lines responded specifically to known immunosuppressants. Further, different pesticides were analysed on these cell lines alone as well as in the presence of activators at IC-10 (chlorpyriphos, $10 \mu \mathrm{g} / \mathrm{ml}$; cypermethrin $10 \mu \mathrm{g} / \mathrm{ml}$ and captan $1 \mu \mathrm{g} /$ $\mathrm{ml}$ ) and two subsequent $1 / 10$ and $1 / 100$ times dilutions of the IC-10 concentration. These pesticides on their own could not alter the basal GFP expression in reporter cell lines (data not presented) but they caused significant alterations in activated jurkat T cells and THP-1 cells.

Chlorpyriphos: PMA/Ionomycin induced GFP expression from

\begin{tabular}{|c|c|}
\hline Cytokine & Primer Sequence $\left(5^{`} \ldots . . . .3^{`}\right)$ \\
\hline IL-2 & $\begin{array}{l}\text { Forward primer } 5^{\circ} \text { GAA AAC ACA GCT ACA ACT GGA GCA T 3` } \\
\text { Reverse primer } 5{ }^{\circ} \text { ATT TAG CAC TTC CTC CAG AGG TTT G } 3^{\circ}\end{array}$ \\
\hline IFN-Y & $\begin{array}{l}\text { Forward primer } 5^{`} \text { TTC AGA TGT AGC GGA TAA TGG AAC } 3^{\star} \\
\text { Reverse primer } 5^{\circ} \text { CCG AAT AAT TAG TCA GCT TTT CGA AG } 3^{\circ}\end{array}$ \\
\hline IL-4 & $\begin{array}{c}\text { Forward primer } 5^{\circ} \text { GAG ATC ATC AAA ACT TTG AAC AGC CT } 3^{\circ} \\
\text { Reverse primer } 5^{\circ} \text { CGT TTC AGG AAT CGG ATC AGC TG } 3^{\circ}\end{array}$ \\
\hline IL-10 & $\begin{array}{c}\text { Forward primer } 5^{\circ} \text { CAA CCT GCC TAA CAT GCT TCG AG } 3^{\prime} \\
\text { Reverse primer } 5^{\circ} \text { ATG ACA GCG CCG TAG CCT CAG } 3^{\prime}\end{array}$ \\
\hline TNF- $\alpha$ & $\begin{array}{l}\text { Forward primer } 5^{\circ} \text { GAC CTC TCT CTA ATC AGC CCT CTG } 3^{\circ} \\
\text { Reverse primer } 5{ }^{\circ} \text { CAG CCT TGG CCC TTG AAG AGG AC } 3^{\circ}\end{array}$ \\
\hline$\beta$-Act & $\begin{array}{l}\text { Forward primer } 5^{\prime} \text { ATC TGG CAC CAC ACC TTC TAC AAT G } 3^{\prime} \\
\text { Reverse primer } 5^{\circ} \text { ATC TTC ATG AGG TAG TCA GTC AGG TC } 3^{\circ}\end{array}$ \\
\hline gfp & $\begin{array}{l}\text { Forword Primer 5' ATGGCTAGCAAAGGAGAAGAACTTTTCAC 3' } \\
\text { Reverse Primer 5'ACACATGGCATGGATGAGCTCTACAAATAA 3' }\end{array}$ \\
\hline GAPDH & $\begin{array}{l}\text { Forword Primer 5'CAT GTT CGT CAT GGG TGT GAA CCA 3' } \\
\text { Reverse Primer 5' AGT GAT GGC ATG GAC TGT GGT CAT 3' }\end{array}$ \\
\hline
\end{tabular}

Table 2: Primers used for amplification of endogenous cytokines by RT PCR. 

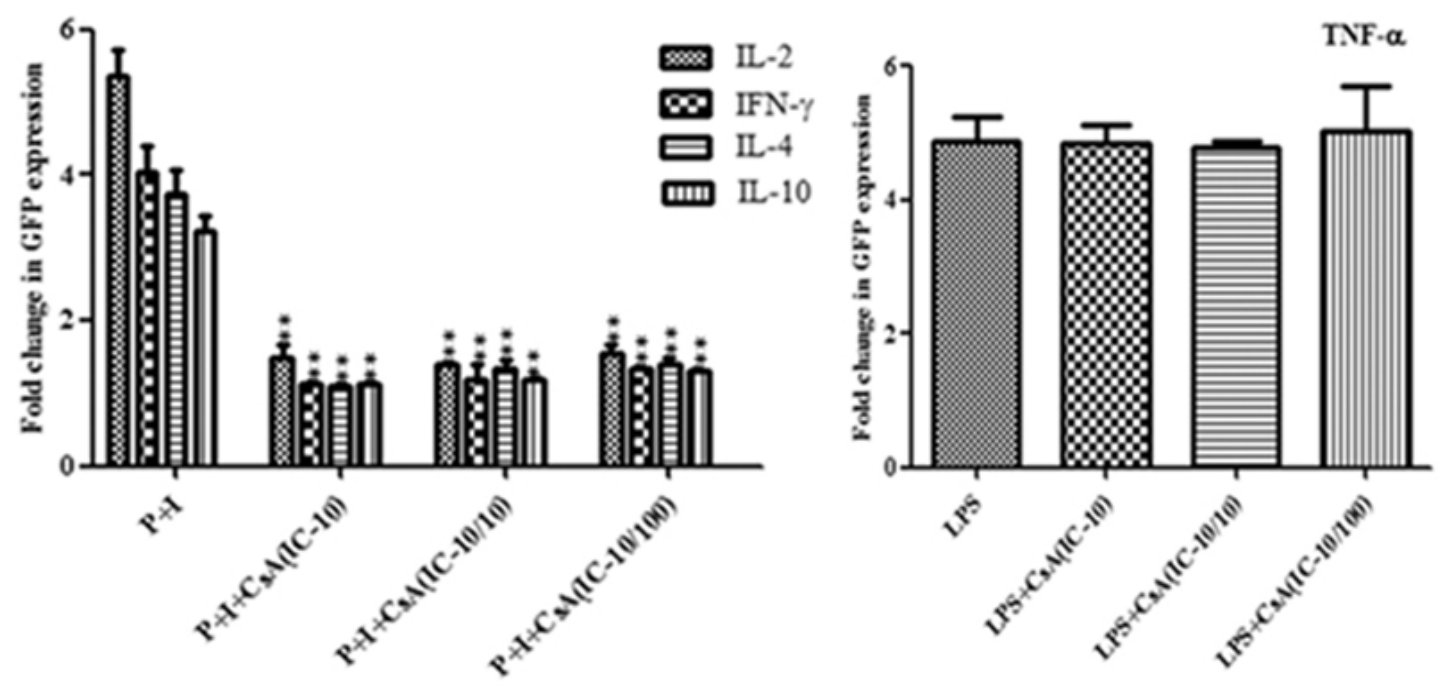

(A)

(B)
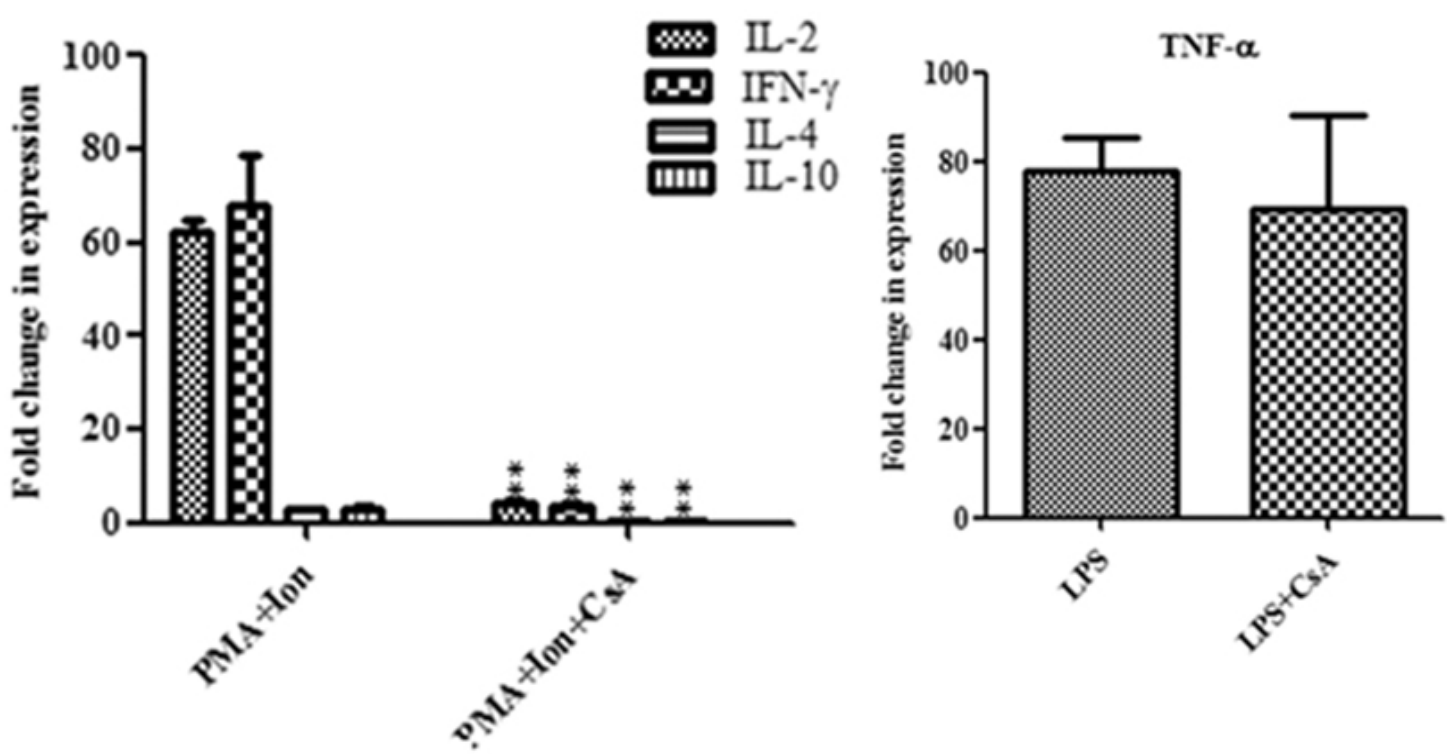

(C)

(D)

Figure 1: Cyclosporine A (CsA) effect on GFP and Cytokine gene expression.. (A) IL-2; IFN- $\mathrm{y}$ :,IL-4; and IL-10 reporter jurkat cell lines were treated with CsA activated by PMA/lonomycin (B) TNF- $\alpha$ reporter THP-1 cell line was treated in presence of LPS at IC-10 (10 $\mathrm{pg} / \mathrm{ml})$ and two concentration of IC10/10 and IC10/100 for $48 \mathrm{~h}$. Relative fold change in expression of GFP from these cell lines was calculated in comparison to expression of GFP in untreated control reporter cells. ) (C) IL-2; IFN-y: IL-4; and IL-10 reporter jurkat cell lines were treated with CsA activated by PMA/lonomycin (D) TNF- $\alpha$ reporter THP-1 cell line was treated in presence of LPS at IC-10 $(10 \mu \mathrm{g} / \mathrm{ml})$ and two concentration of IC10/10 and IC10/100 for $24 \mathrm{~h}$. Real time PCR was done on RNA extracted from these treated cells. Relative fold change in expression of cytokine's gene was calculated in comparison to their expression in untreated control cell. Results are shown as mean fold change \pm SEM $(n=3)$ and change was considered significant at $P \leq 0.05\left(^{*}\right)$ and $P \leq 0.01\left(^{* *}\right)$.

IL-2, IFN- $\gamma$, IL-4 and IL-10 reporter jurkat T cell lines was significantly suppressed by chlorpyriphos treatment at all concentration (Figure 4A). LPS induced GFP expression from TNF- $\alpha$ reporter THP-1 cell line was not altered significantly on treatment with chlorpyriphos at IC-10 as well as at lower concentrations (Figure 4B).

Chlorpyriphos treatment caused suppression of PMA/Ionomycin induced expression of IL-2, IFN- $\gamma$, IL-4 and IL-10 cytokine genes at transcript level (Figure 4C) whereas LPS induced TNF- $\alpha$ gene expression was not suppressed significantly (Figure 4D).
Cypermethrin: moderate suppression of PMA/Ionomycin induced GFP expression from IL-2, IFN- $\gamma$, IL-4 and IL-10 reporter jurkat $\mathrm{T}$ cell line was obtained upon cypermethrin treatment at IC-10 and IC-10/10 concentration. Descending the test concentration further down to IC 10/100 failed to cause any significant suppression (Figure 5A). LPS induced GFP expression from TNF- $\alpha$ reporter THP-1 cell line was not altered significantly at IC-10 as well as at the lower tested concentrations (Figure 5B).

Cypermethrin treatment caused moderate suppression of PMA/ 


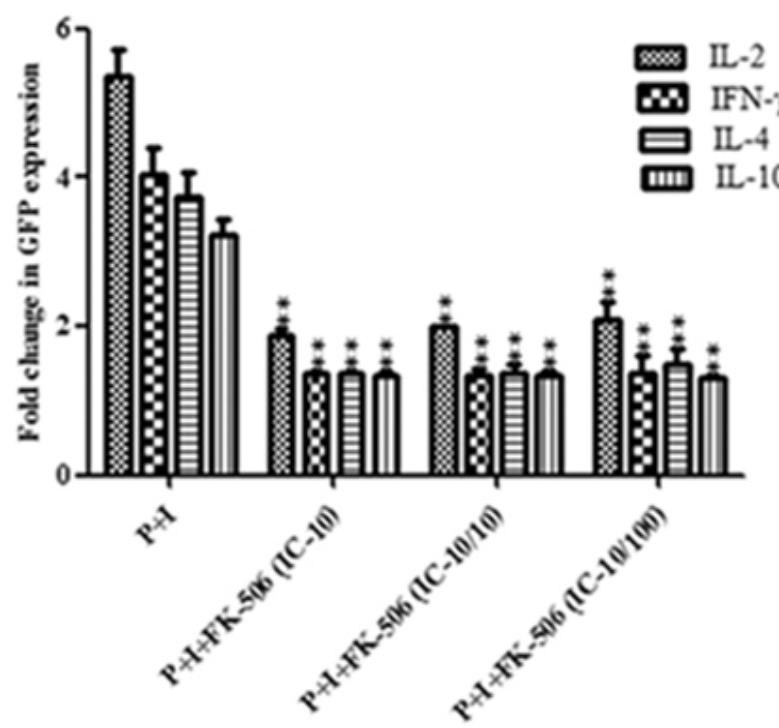

(A)

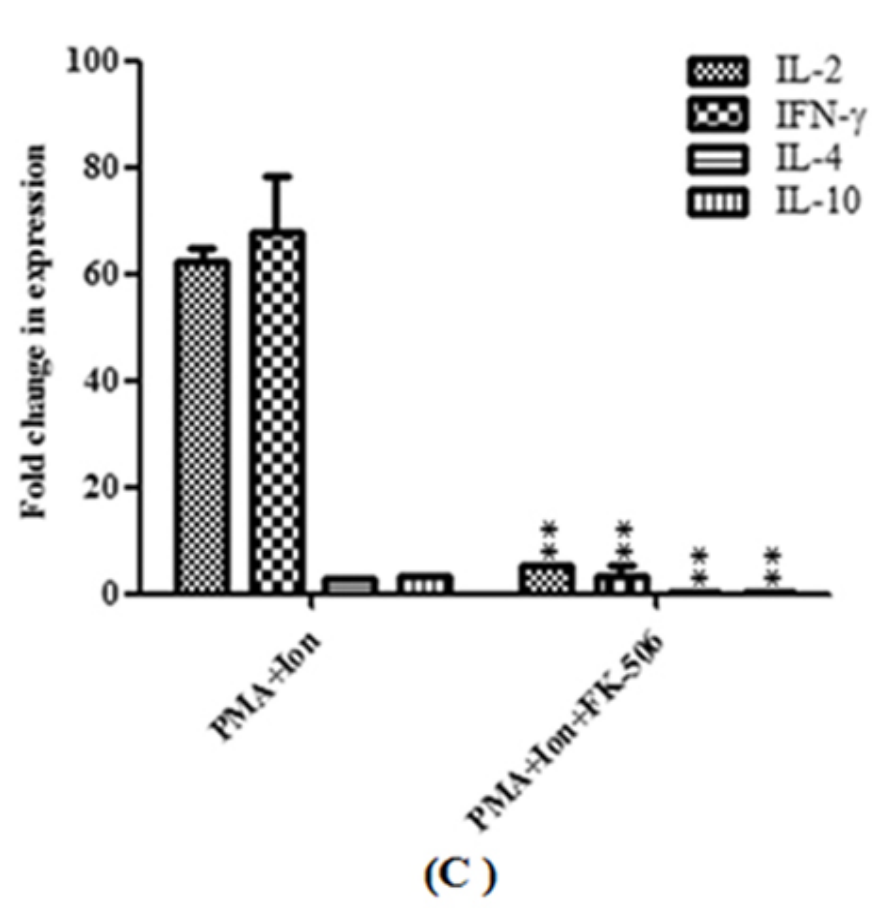

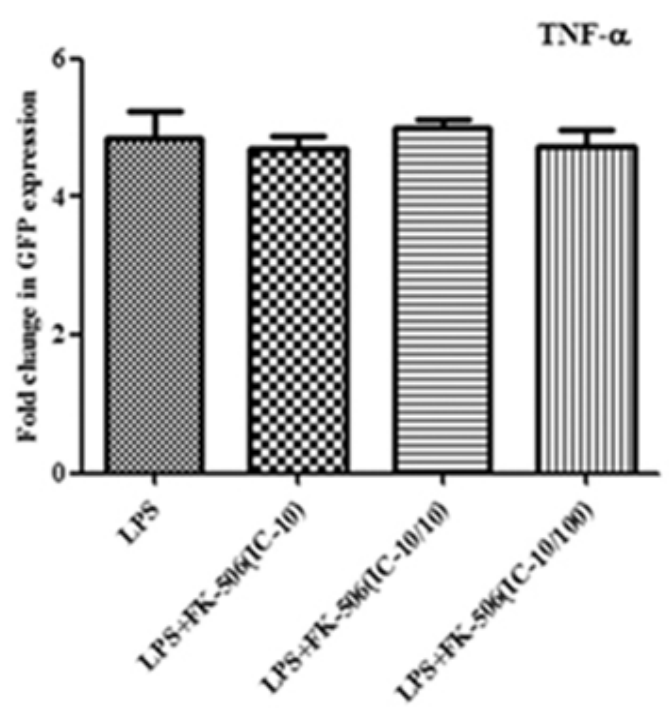

(B)

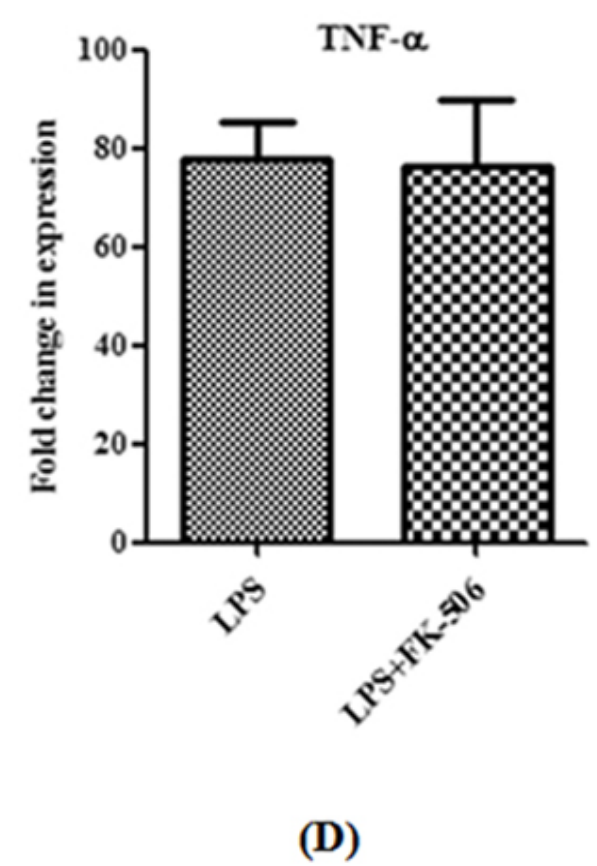

Figure 2: FK506 effect on GFP and Cytokine expression. (A) IL-2; IFN-Y:,IL-4; and IL-10 reporter jurkat cell lines were treated with FK506 activated by PMA/ Ionomycin (B) TNF- $\alpha$ reporter THP-1 cell line was treated in presence of LPS at IC-10 $(8 \mu \mathrm{g} / \mathrm{ml})$ and two concentration of IC10/10 and IC10/100 for $48 \mathrm{~h}$. Relative fold change in expression of GFP from these cell lines was calculated in comparison to expression of GFP in untreated control reporter cells. (C) IL-2; IFN-y: IL-4; and IL10 reporter jurkat cell lines were treated with FK506 activated by PMA/lonomycin (D) TNF- $\alpha$ reporter THP-1 cell line was treated in presence of LPS at IC-10 (8 $\mu$ g/ $\mathrm{ml}$ ) and two concentration of IC10/10 and IC10/100 for $24 \mathrm{~h}$. Real time PCR was done on RNA extracted from these treated cells. Relative fold change in expression of cytokine's gene was calculated in comparison to their expression in untreated control cell. Results are shown as mean fold change \pm SEM ( $n=3$ ) and change was considered significant at $\mathrm{P} \leq 0.05\left(^{*}\right)$ and $\mathrm{P} \leq 0.01\left(^{* *}\right)$.

Ionomycin induced expression of IL-2, IFN- $\gamma$, IL-4 and IL-10 cytokine genes at transcript level (Figure 5C) whereas LPS induced TNF- $\alpha$ gene expression was not suppressed significantly (Figure 5D).

Captan: A moderate suppression of PMA/Ionomycin induced GFP expression from IL-2, IFN- $\gamma$, IL-4 and IL-10 reporter jurkat T cell lines was obtained on captan treatment at IC-10 concentration. On further decreasing the treatment dose to IC10/10 and IC 10/100 only significant suppression was obtained in case of IL-2 and IFN- $\gamma$ (Figure 6A). LPS induced GFP expression from TNF- $\alpha$ reporter cell line was not altered significantly on treatment with captan at IC-10 concentration as well as at all the lower tested concentrations (Figure 6B).

Captan treatment suppressed, PMA /Ionomycin induced 

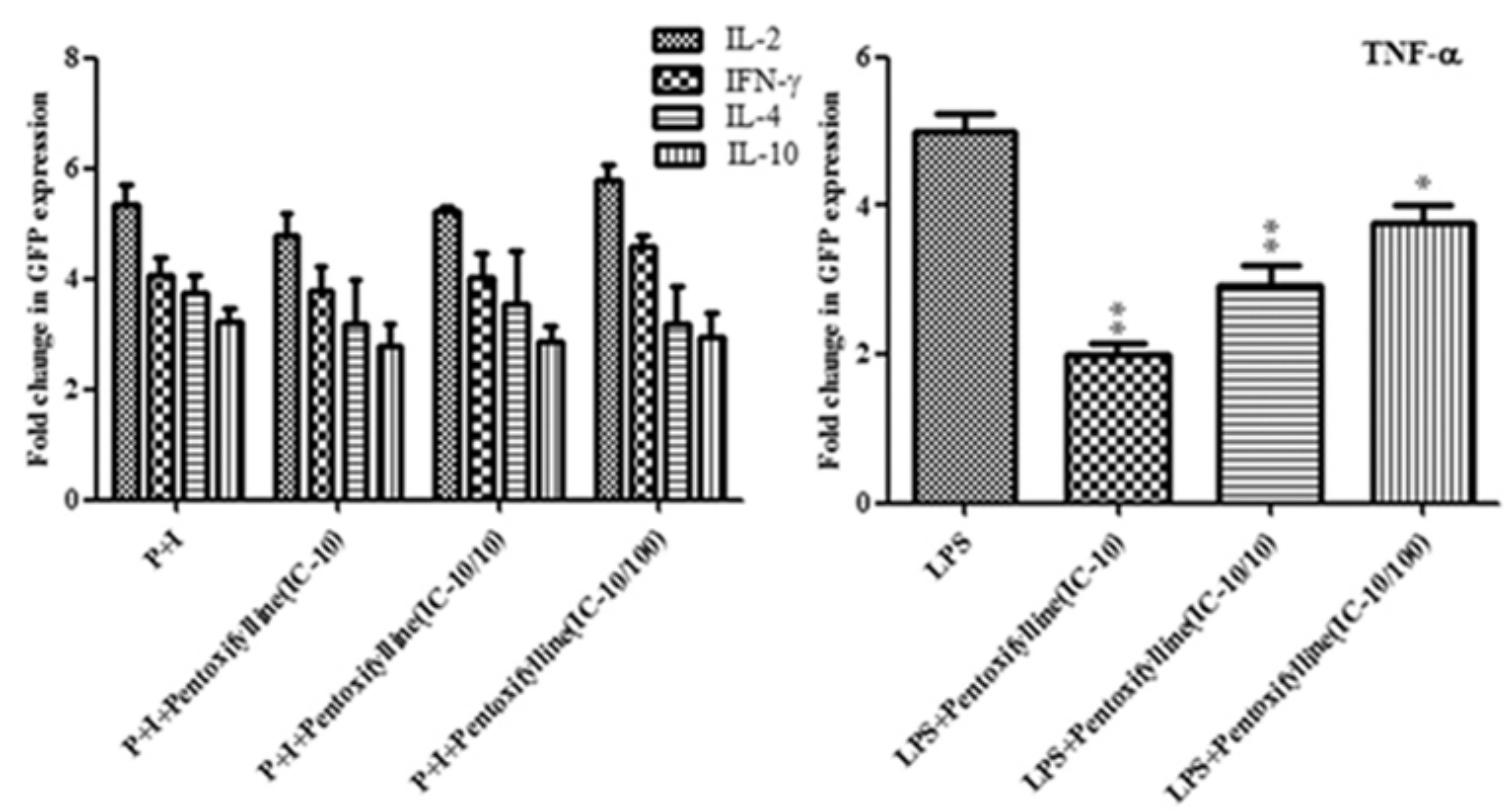

(A)

(B)

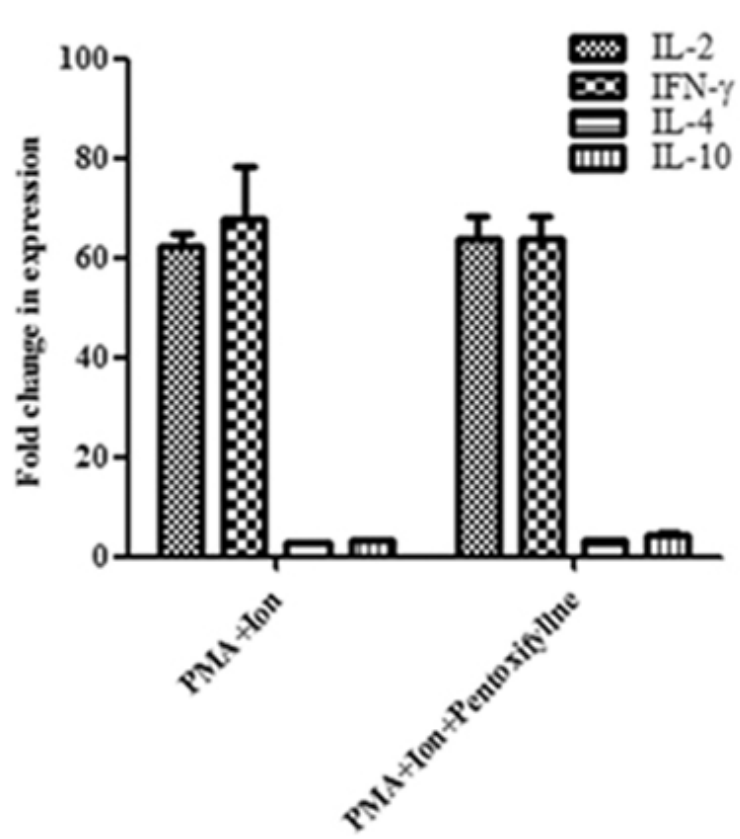

(C)

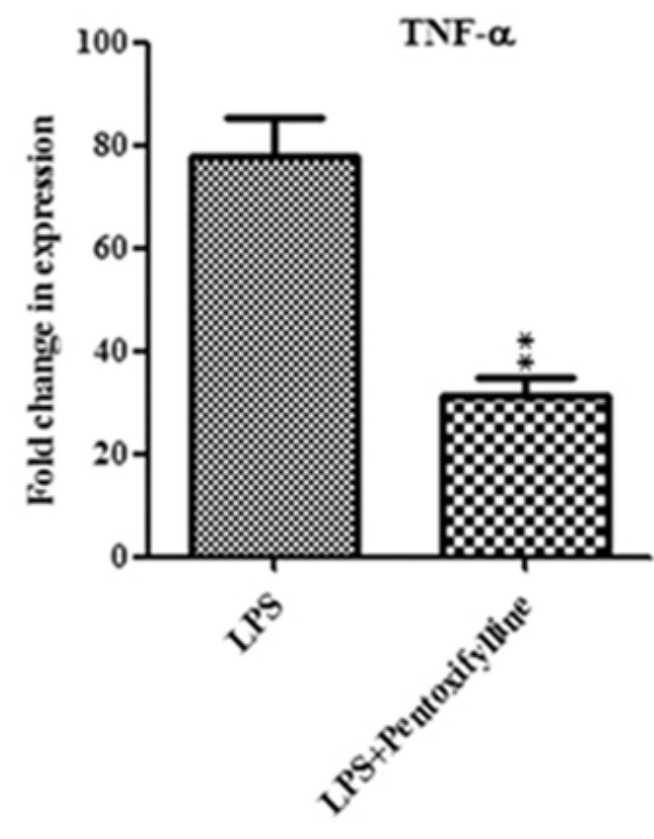

(D)

Figure 3: Pentoxifylline effect on GFP and Cytokine expression. (A) IL-2; IFN-Y:,IL-4; and IL-10 reporter jurkat cell lines were treated with Pentoxifylline activated by PMA/lonomycin (B) TNF- $\alpha$ reporter THP-1 cell line was treated in presence of LPS at IC-10 (27.8 $\mathrm{gg} / \mathrm{ml})$ and two concentration of IC10/10 and IC10/100 for $48 \mathrm{~h}$. Relative fold change in expression of GFP from these cell lines was calculated in comparison to expression of GFP in untreated control reporter cells. (C) IL-2; IFNY:,IL-4; and IL-10 reporter jurkat cell lines were treated with Pentoxifylline activated by PMA/lonomycin (D) TNF- $\alpha$ reporter THP-1 cell line was treated in presence of LPS at IC-10 $(27.8 \mu \mathrm{g} / \mathrm{ml})$ and two concentration of IC10/10 and IC10/100 for $24 \mathrm{~h}$. Real time PCR was done on RNA extracted from these treated cells. Relative fold change in expression of cytokine's gene was calculated in comparison to their expression in untreated control cell. Results are shown as mean fold change \pm $\operatorname{SEM}(n=3)$ and change was considered significant at $P \leq 0.05\left(^{*}\right)$ and $P \leq 0.01\left(^{* *}\right)$.

endogenous expression of IL-2, IFN- $\gamma$, IL-4 gene, suppression of IL10 was however not statistically significant (Figure 6C). LPS induced TNF- $\alpha$ gene expression was neither suppressed nor stimulated to a significant level on captan treatment (Figure6D).
These results show that the pesticides showed immunosuppressor activity on activated Jurkat T cells and have no effect on activated THP1 cells (Table 3 ). Therefore, our model has potential to screen xenobotic compounds that influence immune system by analyzing expression of 
Citation: Thakur D, Singh P, Tripathi C, Bhadauria S, Jain SK, et al. (2013) In Vitro Immunotoxicity Testing of Pesticides using Human Cytokine Promoter Based Reporter Cell Lines. Clin Exp Pharmacol S4: 001. doi:10.4172/2161-1459.S4-001

Page 7 of 12

\begin{tabular}{|c|c|c|c|c|c|c|c|c|c|c|}
\hline \multirow[b]{2}{*}{$\begin{array}{l}\text { Treatment at IC-10 } \\
\text { Concentration }\end{array}$} & \multicolumn{2}{|c|}{ IL- 2} & \multicolumn{2}{|c|}{ IFN-Y } & \multicolumn{2}{|c|}{ IL-4 } & \multicolumn{2}{|c|}{ IL-10 } & \multicolumn{2}{|c|}{ TNF- $\alpha$} \\
\hline & $\begin{array}{l}\text { Reporter } \\
\text { GFP }\end{array}$ & mRNA exp. & $\begin{array}{l}\text { Reporter } \\
\text { GFP }\end{array}$ & mRNA exp. & Reporter GFP & mRNA exp. & $\begin{array}{l}\text { Reporter } \\
\text { GFP }\end{array}$ & mRNA exp. & Reporter GFP & mRNA exp. \\
\hline PMA+ Ion & $5.35 \pm 0.498$ & $62.22 \pm 3.98$ & $4.05 \pm 0.47$ & $67.66 \pm 15.36$ & $3.75 \pm 0.44$ & $2.85 \pm 0.27$ & $3.21 \pm 0.33$ & $3.180 \pm 0.29$ & & \\
\hline $\mathrm{P}+\mathrm{I}+\mathrm{CSA}(10 \mu \mathrm{g} / \mathrm{ml})$ & $1.48 \pm 0.26$ & $4.46 \pm 0.48$ & $1.13 \pm 0.02$ & $3.60 \pm 0.58$ & $1.11 \pm 0.004$ & $0.62 \pm 0.10$ & $1.13 \pm 0.03$ & $0.36 \pm 0.05$ & & \\
\hline $\begin{array}{l}\text { P+l +FK506 } \\
(8 \mu \mathrm{g} / \mathrm{ml})\end{array}$ & $1.87 \pm 0.12$ & $5.39 \pm 0.40$ & $1.37 \pm .021$ & $3.4 \pm 2.8$ & $1.38 \pm 0.01$ & $0.259 \pm 0.002$ & $1.33 \pm 0.084$ & $0.57 \pm 0.005$ & & \\
\hline $\begin{array}{l}\text { P+l+Pentoxifylline } \\
(27.8 \mu \mathrm{g} / \mathrm{ml})\end{array}$ & $4.77 \pm 0.57$ & $63.7 \pm 6.63$ & $3.791 \pm 0.59$ & $63.82 \pm 6.519$ & $3.205 \pm 1.11$ & $3.12 \pm 0.49$ & $2.80 \pm 0.54$ & $4.41 \pm 0.685$ & & \\
\hline $\begin{array}{l}\text { P+l+Chlorpyriphos } \\
(10 \mu \mathrm{g} / \mathrm{ml})\end{array}$ & $2.16 \pm 0.21$ & $9.27 \pm 0.424$ & $1.49 \pm 0.12$ & $6.79 \pm 3.88$ & $1.38 \pm 0.21$ & $0.268 \pm 0.01$ & $1.54 \pm 0.413$ & $0.622 \pm 0.04$ & & \\
\hline $\begin{array}{l}\text { P+l+Cypermethin } \\
(10 \mu \mathrm{g} / \mathrm{ml})\end{array}$ & $3.00 \pm 0.26$ & $41.87 \pm 5.38$ & $12.19 \pm 0.22$ & $37.24 \pm 11.92$ & $2.08 \pm 0.38$ & $1.42 \pm 0.278$ & $\begin{array}{c}1.240 \pm \\
0.169\end{array}$ & $\begin{array}{c}0.857 \pm \\
0.160\end{array}$ & & \\
\hline $\mathrm{P}+\mathrm{I}+$ Captan $(1 \mu \mathrm{g} / \mathrm{ml})$ & $3.49 \pm 0.28$ & $43.7 \pm 5.69$ & $2.54 \pm 0.26$ & $45.8 \pm 2.69$ & $2.52 \pm 0.54$ & $1.44 \pm 0.28$ & $2.11 \pm 0.05$ & $2.9 \pm 0.28$ & & \\
\hline LPS & & & & & & & & & $4.87 \pm 0.51$ & $77.81 \pm 10.65$ \\
\hline LPS+CSA $(10 \mu \mathrm{g} / \mathrm{ml})$ & & & & & & & & & $4.86 \pm 0.36$ & $69.37 \pm 29.51$ \\
\hline $\begin{array}{l}\text { LPS+FK506 } \\
(8 \mu \mathrm{g} / \mathrm{ml})\end{array}$ & & & & & & & & & $4.710 \pm 0.25$ & $76.24 \pm 19.17$ \\
\hline $\begin{array}{l}\text { LPS+Pentoxifilline } \\
(27.8 \mu \mathrm{g} / \mathrm{ml})\end{array}$ & & & & & & & & & $2.01 \pm 0.24$ & $30.51 \pm 3.58$ \\
\hline $\begin{array}{l}\text { LPS+Chlorpyriphos } \\
(10 \mu \mathrm{g} / \mathrm{ml})\end{array}$ & & & & & & & & & $4.85 \pm 0.8$ & $79.96 \pm 12.65$ \\
\hline $\begin{array}{l}\text { LPS+Cypermethrin } \\
(10 \mu \mathrm{g} / \mathrm{ml})\end{array}$ & & & & & & & & & $4.9 \pm 0.32$ & $80.94 \pm 7.9$ \\
\hline $\begin{array}{l}\text { LPS+Captan }(1 \mu \mathrm{g} / \\
\mathrm{ml})\end{array}$ & & & & & & & & & $5.27 \pm 0.7$ & $82.28 \pm 5.57$ \\
\hline
\end{tabular}

Table 3: Reporter gene and endogenous cytokine gene expression after treatment with immunosuppressant and chemicals at IC-10 concentration in activated cells.

reporter gene regulated by regulatory regions of cytokines. This model helps for fast screening of compounds of all class based on cytokine gene response which is implicated in Th1 and Th 2 type of immune response.

\section{Discussion}

We have developed an alternative in vitro model based on transformed human cell lines for the purpose of immunotoxicity testing of xenobiotics. This model was based on the expression of signature cytokines of Th1 and Th2 type of immune responses and inflammatory cytokine expression by macrophages. Lymphoid and myeloid cells represent two distinct lineages that are integral to functional immune system. Therefore, so as to ascertain the lineage specificity of the response we selected two different cell lines, with each one representing one particular lineage of cells. While Jurkat $\mathrm{T}$ cells represent lymphoid lineage cells (T cells), THP-1 cells represent myeloid lineage cells (Macrophages/momocytes). The Jurkat $\mathrm{T}$ cells were stably transformed with GFP reporter constructs regulated by IL- 2 , IFN- $\gamma$, IL- 4 and IL-10 gene regulatory regions. THP- 1 cells were stably transformed with GFP reporter regulated by TNF- $\alpha$ gene regulatory region. This model was validated using immunosuppressant CsA and FK506. Our model successfully predicted immunosuppressant activity of known immunosuppressant CsA and FK506 in jurkat transformed cell lines stimulated with immunostimulators PMA/ Ionomycin and pentoxyfilline induced suppression in LPS activated THP-1 cells. PMA/Ionomycin has been reported to induce $\mathrm{T}$ cell activation and cytokine secretion; PMA activates protein kinase $\mathrm{C}$ (PKC), leading to initiation of the signaling cascades responsible for the nuclear localisation of transcription factor AP-1 and NFKB, while ionomycin causes a release of intracellular calcium stores resulting in increased nuclear localisation of transcription factor NFAT. Thus, treatment with both PMA and ionomycin leads to increased nuclear localisation of these transcription factors which regulates expression of IL-2, IFN- $\gamma$, IL- 4 and IL-10 cytokines resulting in increased expression of these cytokines [25]. Induction of reporter gene expression on PMA/
Ionomycin treatment, from IL-2, IFN- $\gamma$, IL-4 and IL-10 reporter Jurkat $\mathrm{T}$ cell lines is in accordance with previous reports and established the functionality of the cloned regulatory region. Lipopolysaccharides (LPS) a known macrophage activator, activates a complex signalling network including the activation of nuclear factor kappa $\mathrm{B}(\mathrm{NF \kappa B})$ and mitogen-activated protein kinase (MAPK) pathways ultimately leading to the expression of TNF and other inflammatory factors [26]. LPS treatment induced GFP upregulation in THP-1 cells (monocytic cell line) that were stably expressing regulatory region of TNF- $\alpha$ and was in agreement with previous report thus established the functionality of the cloned regulatory region [27].

In our model, immunosuppressive drug cyclosporine (CsA) and FK506 were found to suppress PMA/Ionomycin induced GFP expression in IL-2, IFN- $\gamma$, IL-4 and IL-10 reporter cell lines. CsA has been reported to bind with cytoplasmic protein cyclophilin, forming a complex that blocks the phosphatase activity of calcineurin which in turn prevents NFAT activation and its translocation to nucleus thus preventing NFAT regulated expression of cytokines. Similarly FK506 has been reported to bind with cytoplasmic proteins called FKBP, forming a complex that blocks the phosphatase activity of calcineurin which in turn prevents NFAT activation and translocation to nucleus thus preventing NFAT regulated expression of cytokines [28]. Suppression of PMA/Ionomycin induced GFP expression from IL-2, IFN- $\gamma$, IL-4 and IL-10 reporter cell line on CsA and FK506 treatment is thus justified. LPS induced GFP expression from TNF- $\alpha$ reporter cell line was not suppressed by CsA as well as FK506. This was in agreement with previous studies wherein they have demonstrated that LPS induced TNF- $\alpha$ stimulation remains unaffected by CsA and FK506 treatment $[29,30]$.

Immunomodulatory activity of pesticides has been reported previously in different animal model and human case studies. Immunological parameters in pesticide applicators exposed to a mixture of oraganophosphates (OPs), carbamates, phenoxy herbicides and pyrethoids was examined [10]. 


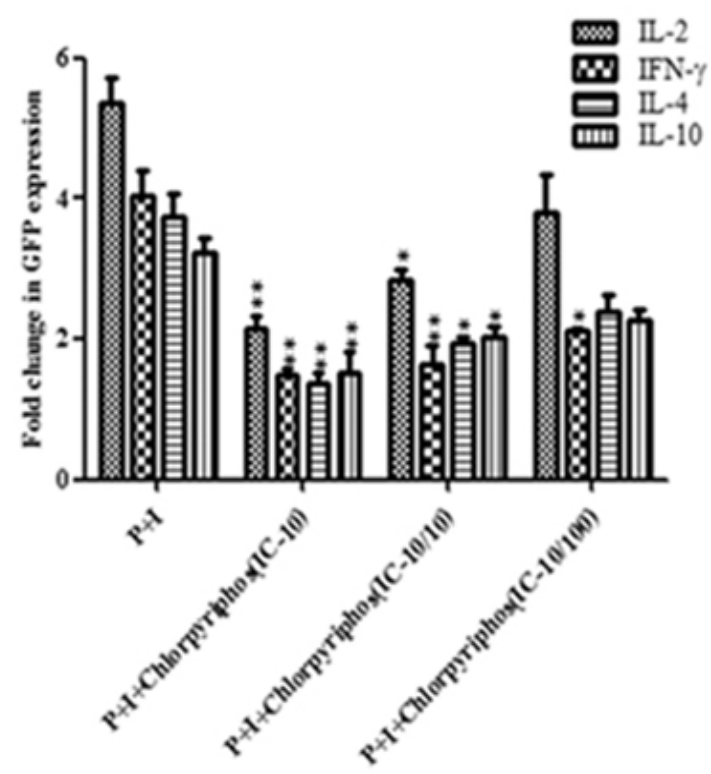

(A)

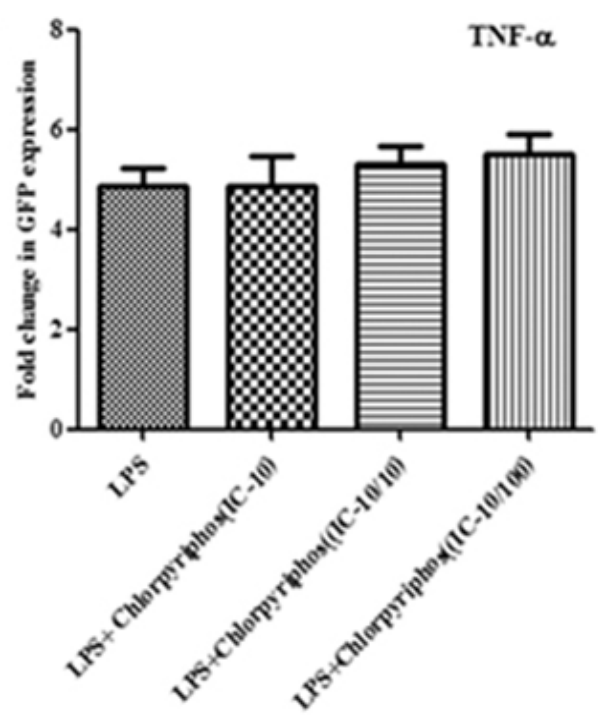

(B)
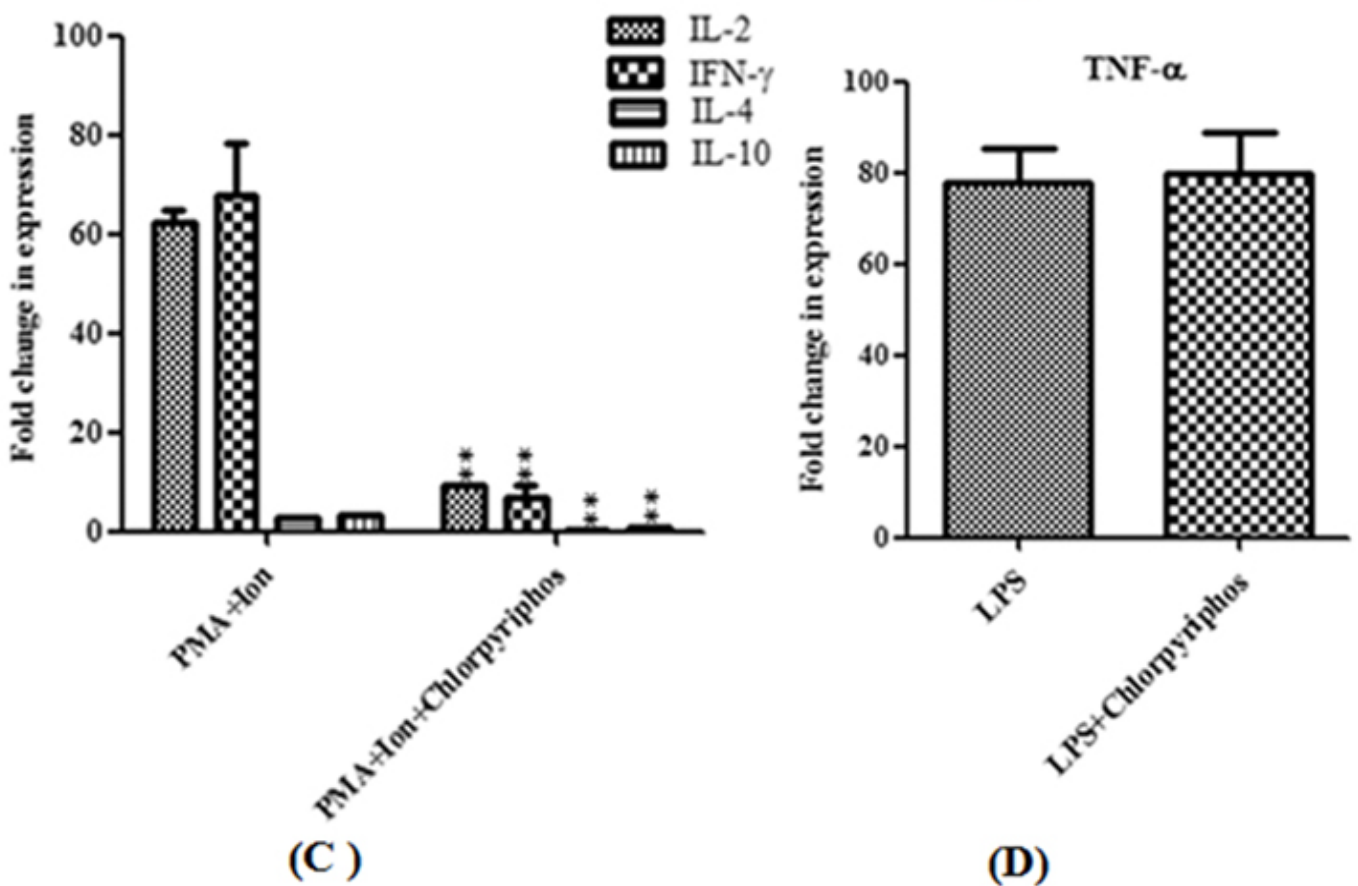

(D)

Figure 4: Chlorpyriphos effect on GFP and Cytokine expression. . (A) IL-2; IFN-Y:,IL-4; and IL-10 reporter jurkat cell lines were treated with Chlorpyriphos activated by PMA/lonomycin (B) TNF- $\alpha$ reporter THP-1 cell line was treated in presence of LPS at IC-10 (10 $\mathrm{\mu g} / \mathrm{ml})$ and two concentration of IC10/10 and IC10/100 for $48 \mathrm{~h}$. Relative fold change in expression of GFP from these cell lines was calculated in comparison to expression of GFP in untreated control reporter cells. (C) IL-2; IFN-y:,IL-4; and IL-10 reporter jurkat cell lines were treated with Chlorpyriphos activated by PMA/lonomycin (D) TNF- $\alpha$ reporter THP-1 cell line was treated in presence of LPS at IC-10 $(10 \mathrm{\mu g} / \mathrm{ml})$ and two concentration of IC 10/10 and IC10/100 for $24 \mathrm{~h}$. Real time PCR was done on RNA extracted from these treated cells. Relative fold change in expression of cytokine's gene was calculated in comparison to their expression in untreated control cell. Results are shown as mean fold change $\pm \operatorname{SEM}(n=3)$ and change was considered significant at $P \leq 0.05\left(^{*}\right)$ and $P \leq 0.01\left(^{* *}\right)$.

Chlorpyriphos, an organophosphorus (OP) insecticide is used to control a wide range of pests, such as cutworms, corn rootworms, cockroaches, grubs, flea beetles, flies, termites, fire ants, and lice. This compound is applied to different crops including cotton, nuts, vegetables and ornamental plants, and may enter surface water by runoff, spraydrift, or accidental spills [31]. It exhibits moderate persistence in natural systems and has low solubility in water [32,33]. In our model, chlorpyriphos caused significant suppression of PMA/ 


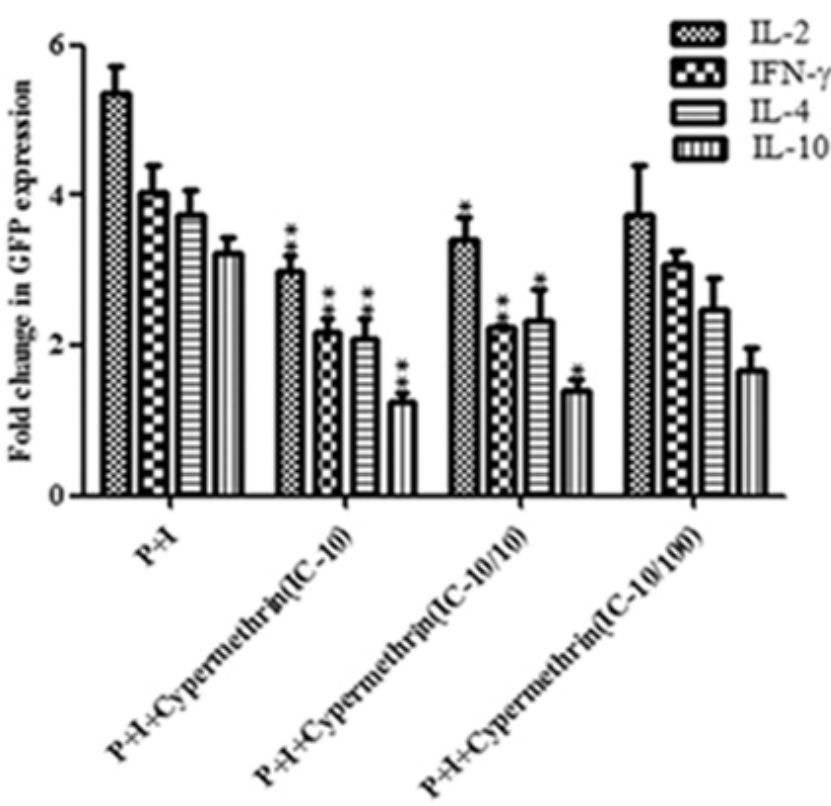

(A)

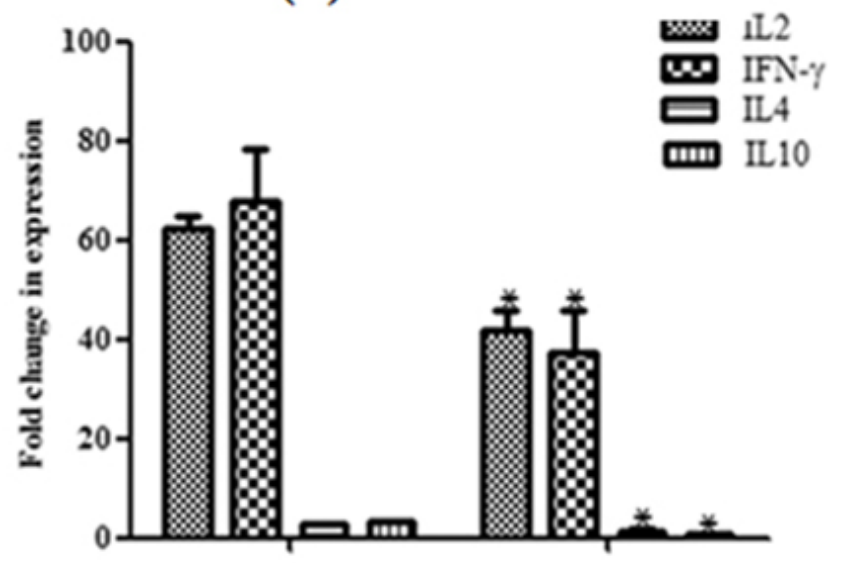

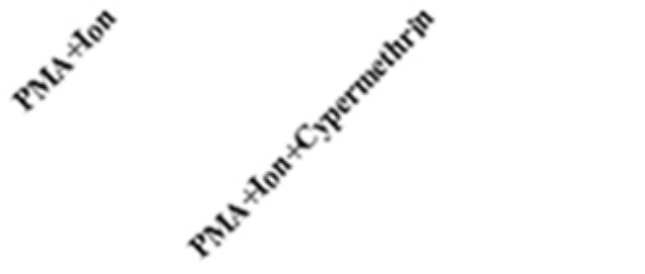

(C)

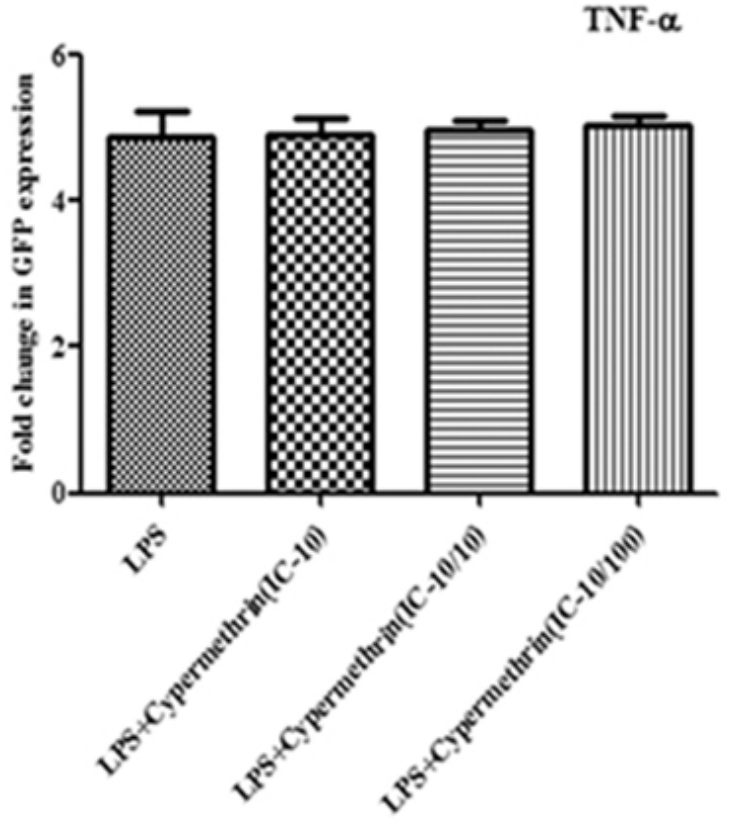

(B)

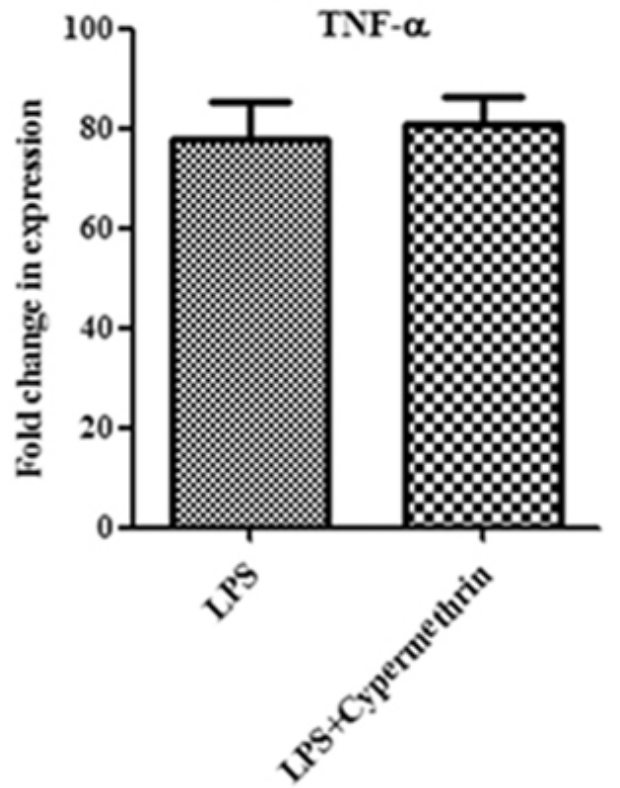

(D)

Figure 5: Cypermethrin effect on GFP and Cytokine expression. (A) IL-2; IFN-Y:,IL-4; and IL-10 reporter jurkat cell lines were treated with Cypermethrin activated

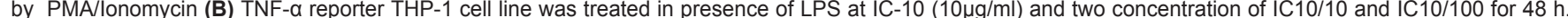
Relative fold change in expression of GFP from these cell lines was calculated in comparison to expression of GFP in untreated control reporter cells. (C) IL-2; IFN$\mathrm{Y}$ :,IL-4; and IL-10 reporter jurkat cell lines were treated with Cypermethrin activated by PMA/lonomycin (D) TNF- $\alpha$ reporter THP-1 cell line was treated in presence of LPS at IC-10 $(10 \mu \mathrm{g} / \mathrm{ml})$ and two concentration of IC10/10 and IC10/100 for $24 \mathrm{~h}$. Real time PCR was done on RNA extracted from these treated cells. Relative fold change in expression of cytokine's gene was calculated in comparison to their expression in untreated control cell. Results are shown as mean fold change \pm SEM $(n=3)$ and change was considered significant at $P \leq 0.05\left(^{*}\right)$ and $P \leq 0.01\left(^{* *}\right)$.

Ionomycin induced GFP expression from IL-2, IFN- $\gamma$, IL-4 and IL-10 reporter cell lines at IC-10 and IC-10/10 concentration which suggests immunosuppressive action of chlorpyriphos. Recent research has identified immune system abnormalities in individuals exposed to chlorpyrifos. Higher than usual frequencies of allergies and sensitivities to antibiotics together with atypical abundances of certain types of lymphocytes (decrease in T cells and increase in CD26 cells) were found in patients exposed to chlorpyrifos for a period ranging from 


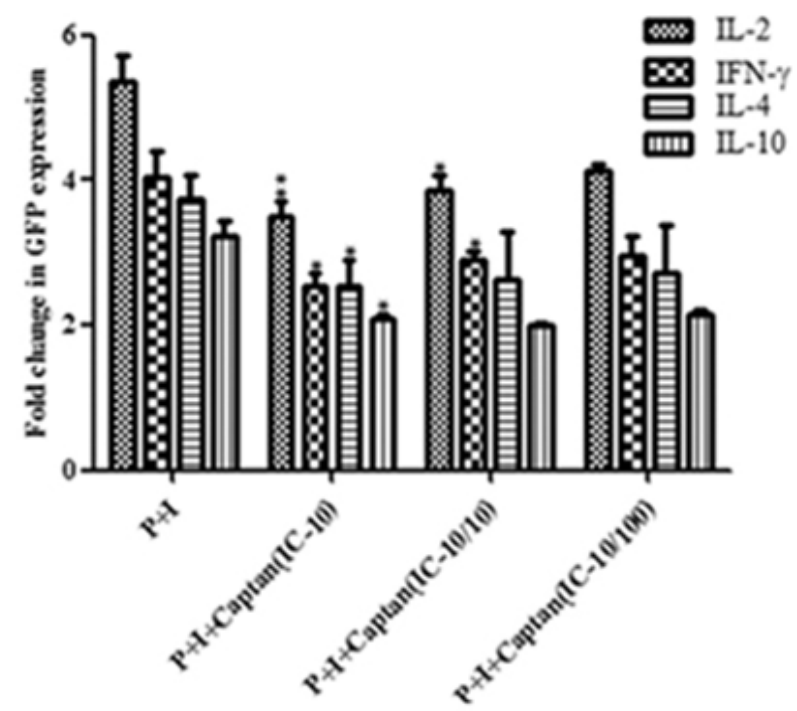

(A)

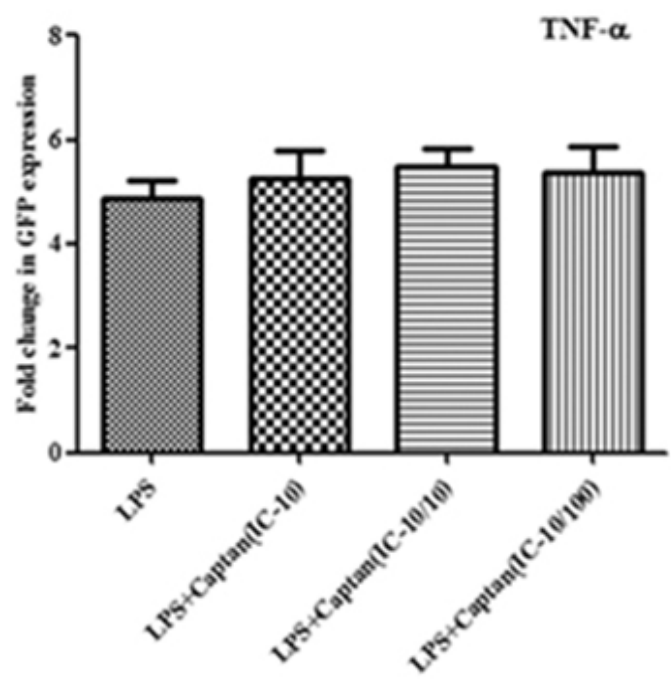

(B)
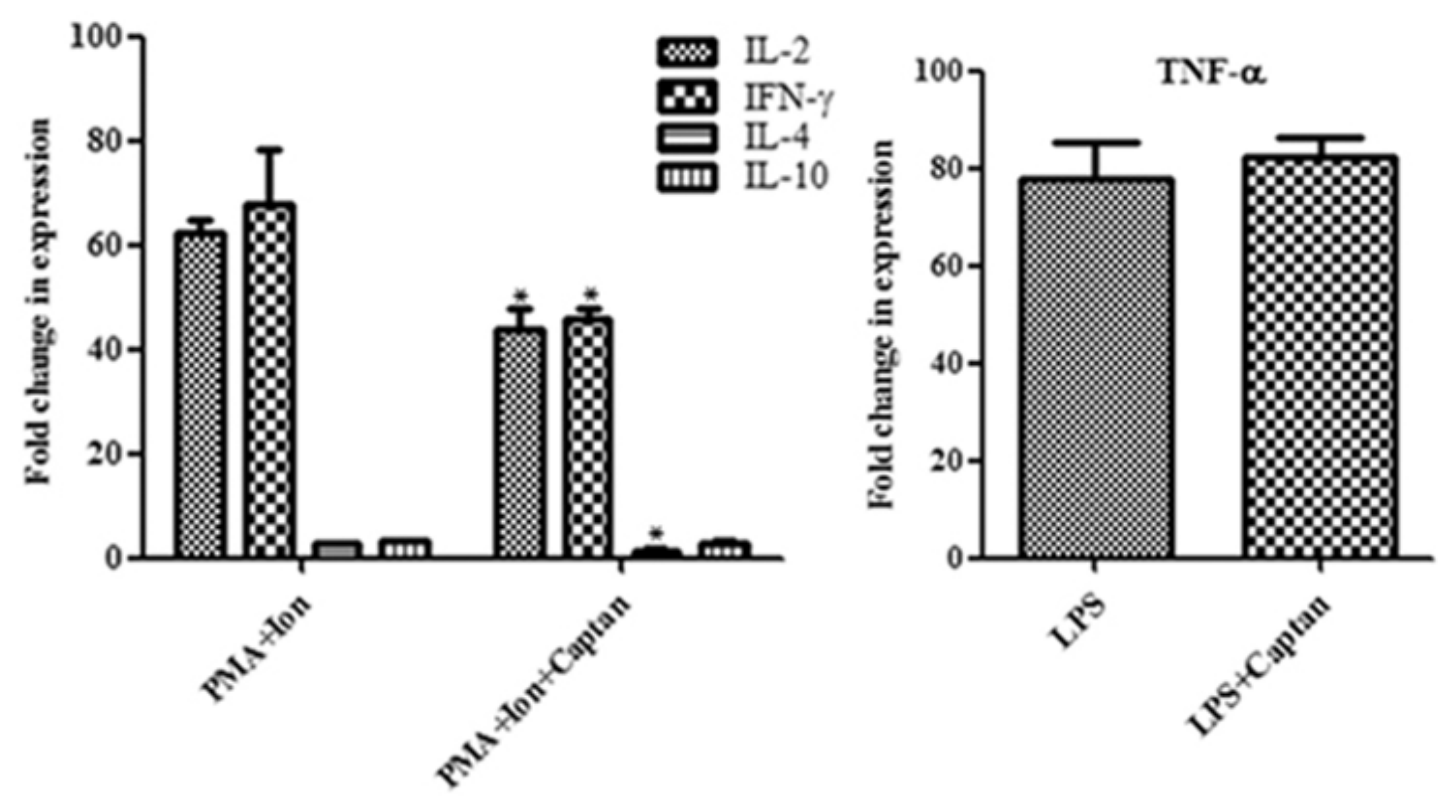

(C)

(D)

\begin{abstract}
Figure 6: Captan effect on GFP and Cytokine expression. . (A) IL-2; IFN-Y:,IL-4; and IL-10 reporter jurkat cell lines were treated with Captan activated by PMA/

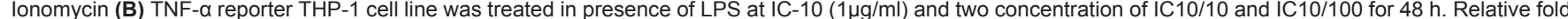
change in expression of GFP from these cell lines was calculated in comparison to expression of GFP in untreated control reporter cells. (C) IL-2; IFN-Y: IL-4; and IL10 reporter jurkat cell lines were treated with Captan activated by PMA/lonomycin (D) TNF- $\alpha$ reporter THP-1 cell line was treated in presence of LPS at IC-10 (1 $\mu \mathrm{g} /$ $\mathrm{ml}$ ) and two concentration of IC10/10 and IC10/100 for $24 \mathrm{~h}$. Real time PCR was done on RNA extracted from these treated cells. Relative fold change in expression of cytokine's gene was calculated in comparison to their expression in untreated control cell. Results are shown as mean fold change \pm SEM $(n=3)$ and change was considered significant at $\mathrm{P} \leq 0.05\left(^{*}\right)$ and $\mathrm{P} \leq 0.01{ }^{(*)}$.
\end{abstract}

one to five years [34]. Chlorpyrifos was found to impair T-lymphocyte blastogenesis induced by concanavalin $\mathrm{A}$ and phytohemagglutinin but did not alter the $\mathrm{B}$ lymphocyte blastogenesis induced by lipopolysaccharide/dextran in rat [35]. These reports support the immunosuppressive action of chlorpyriphos on $\mathrm{T}$ cell population as observed in our study.

Cypermethrin, a pyrethroid insecticide is a constituent of many household insecticides. In our model cypermethrin caused significant 
Citation: Thakur D, Singh P, Tripathi C, Bhadauria S, Jain SK, et al. (2013) In Vitro Immunotoxicity Testing of Pesticides using Human Cytokine Promoter Based Reporter Cell Lines. Clin Exp Pharmacol S4: 001. doi:10.4172/2161-1459.S4-001

Page 11 of 12

suppression of PMA/Ionomycin induced GFP expression within IL2 , IFN- $\gamma$, IL- 4 and IL-10 reporter cell lines at IC-10 and IC-10/10 concentration which suggests immunosuppressive action of this compound. There have been many reports of immunomodulation caused by this insecticide; recently Sankar et al. [36], reported a significant decline in antibody titre in cypermethrin treated rats suggesting cypermethrin-induced immunosuppression. Similarly, Stelzer and Gordon (1984) showed that cypermethrin inhibited the proliferation of mouse $\mathrm{T}$ and $\mathrm{B}$ cells at 10 to $50 \mu \mathrm{M}$ concentration range [37]. Tamang et al. reported in vivo immunosuppressive effect of cypermethrin in mice and goats [38]. Their results revealed significant suppression of cell mediated immunity in both the species, and humoral immune response in goats. Cypermethrin given in feed at a concentration of $100 \mathrm{ppm}$ for 8 weeks was also found to cause significant depression in DTH reaction in broiler chickens [39].

Captan, a nonsystemic phthalimide fungicide is used to control diseases of many fruit, ornamental, and vegetable crops. In our model captan caused moderate but significant suppression of PMA/Ionomycin induced GFP expression from IL-2, IFN- $\gamma$, IL-4 and IL-10 reporter cell lines at IC-10 concentration, confirming immunosuppressive action of this compound. The effect of short-term oral administration of captan, on the immune response was studied in rats and mice [40]. The SRBCantibody formation, lymphoblastic stimulation of spleenic cells by PHA and by LPS was depressed in both species after 14 days of captan treatment. These results pointed out a clear depressive effect of captan diet on the immune response of the animals which goes in line with our results.

There have been previous reports of using cytokines promoter based reporter cell lines for immunotoxicity testing. Ulleras et al. have used cell lines of murine origin and EGFP as reporter gene; quantitation of reporter gene expression was done by flow cytometry [41]. Ootsingh et al. have used cell lines of human origin and luciferase as reporter gene [42]. We have used lymphoid and myeloid cell lines of human origin and GFP as reporter gene a combination of both the reports. Owing to this, our model has two advantages. Use of cell lines of human origin instead of murine origin makes it a better representative of responses likely to occur in humans. Secondly, employing GFP as a reporter gene makes our model a cost effective means of high throughput screening. The immunotoxicity occurring due to metabolic activation of test agents cannot be evaluated in current system. Our model showed the immunotoxic effect on Jurkat T cells expressing IL2 , IFN- $\gamma$, IL-4, and IL-10 reporter cells but showed no effect on THP-1 reporter cells which showed the same effect in humans on exposure of these pesticides. All these pesticides tested on this model were found to have immunosuppressive activity on expression of Th1 and Th2 cytokines which can be supported by previous immunotoxicity studies pertaining to these pesticides. So this model can be employed for rapid high throughput immunotoxicity screening of pesticides and other compounds for rapid screening to identify the immunotixic potential of xenobiotics

\section{Acknowledgement}

This work was supported by CSIR Networking project NWP0034

Note: This manuscript bears CDRI communication no. 188/201/RKT.

\section{References}

1. Alavanja MC (2009) Introduction: pesticides use and exposure extensive worldwide. Rev Environ Health 24: 303-309.

2. Winand K. Hock, EricS. Lorenz (2006) Pesticide Safety Fact Sheet: Toxicity of Pesticides. The Pennsylvania State University, 112 Agricultural Administration Building, University Park, PA 16802.
3. Nesheim ON, Fishel FM, and Mossler M (2011) Toxicity of Pesticides UF|University of Florida IFAS Exten. PI-13/PI008.

4. Nalwanga E, Ssempebwa JC (2011) Knowledge and practices of in-home pesticide use: a community survey in Uganda. J Environ Public Health 2011 230894.

5. WHO Reports (2006) Pesticides are a leading suicide method. http://www.who int/mediacentre/news/notes/2006/np24/en/

6. Repetto R, Baliga S (1996) Trends and patterns of pesticide use: In Pesticides and the immune system; Public Health Risks, 3-8. World Resources Institute Washington, D.C.

7. Nishimoto S, Kanda K, Okabe M, Akiyama K, Kakinuma $Y$ et al (2009) Abnormal Response Induced by Pesticides on Mammalian Immune System. Interdisciplinary Studies on Environmental Chemistry-Environmental Research in Asia. 211-217.

8. Blakley BR, Yole MJ, Brousseau P, Boermans H, Fournier M (1999) Effect of chlorpyrifos on immune function in rats. Vet Hum Toxicol 41: 140-144.

9. Stiller-Winkler R, Hadnagy W, Leng G, Straube E, Idel H (1999) Immunological parameters in humans exposed to pesticides in the agricultural environment. Toxicol Lett 107: 219-224.

10. Zakerinia M, Namdari M, Amirghofran S (2012) The Relationship between Exposure to Pesticides and the Occurrence of Lymphoid Neoplasm. Iran Red Crescent Med J 14: 337-344.

11. Van Loveren H, Krajnc El, Vos JG (1988) Development of a testing battery to assess chemical-induced immunotoxicity. Fundam Appl Toxicol 11: 731-732.

12. Descotes J, Nicolas B, Vial T (1995) Assessment of immunotoxic effects in humans. Clin Chem 41: 1870-1873.

13. Pallardy M, Kerdine S, Lebrec $\mathrm{H}$ (1998) Testing strategies in immunotoxicology Toxicol Lett 102-103: 257-60.

14. House VR, Descotes J (2007) Cytokines in Human Health: Immunotoxicology Pathology, and Therapeutic applications. Methods in pharmacology and toxicology Humana press, USA

15. Oliveira DB, Gillespie K, Wolfreys K, Mathieson PW, Qasim F, et al. (1995) Compounds that induce autoimmunity in the brown Norway rat sensitize mast cells for mediator release and interleukin-4 expression. Eur J Immunol 25: 2259-2264.

16. Dastych J, Walczak-Drzewiecka A, Wyczolkowska J, Metcalfe DD (1999) Murine mast cells exposed to mercuric chloride release granule-associated $\mathrm{N}$-acetyl-beta-D-hexosaminidase and secrete IL-4 and TNF-alpha. J Allergy Clin Immunol 103: 1108-1114.

17. Corsini E, Codecà I, Mangiaratti S, Birindelli S, Minoia C, et al. (2007) Immunomodulatory effects of the herbicide propanil on cytokine production in humans: In vivo and in vitro exposure. Toxicol Appl Pharmacol 222: 202-210.

18. Duramad P, Tager IB, Holland NT (2007) Cytokines and other immunologica biomarkers in children's environmental health studies. Toxicol Lett 172: 48-59.

19. Duramad P, Harley K, Lipsett M, Bradman A, Eskenazi B, et al. (2006) Early environmental exposures and intracellular Th1/Th2 cytokine profiles in 24-month-old children living in an agricultural area. Environ Health Perspect 114: 1916-1922.

20. Hayley S, Mangano E, Crowe G, Li N, Bowers WJ (2011) An in vivo anima study assessing long-term changes in hypothalamic cytokines following perinatal exposure to a chemical mixture based on Arctic maternal body burden. Environ Health 10: 65.

21. Yamaoka KA, Miyasaka N, Inuo G, Saito I, Kolb JP, et al. (1994) 1,1 '-Ethylidenebis(tryptophan) (Peak E) induces functional activation of human eosinophils and interleukin 5 production from $\mathrm{T}$ lymphocytes: association of eosinophilia-myalgia syndrome with a L-tryptophan contaminant. J Clin Immunol 14: 50-60.

22. Corsini E, Primavera A, Marinovich M, Galli CL (1998) Selective induction of cell-associated interleukin-1alpha in murine keratinocytes by chemical allergens. Toxicology 129: 193-200.

23. Vandebriel RJ, Spiekstra SW, Hudspith BN, Meredith $C$, Van Loveren $H$ (1999) In vitro exposure effects of cyclosporin A and bis(tri-n-butyltin)oxide on lymphocyte proliferation, cytokine (receptor) mRNA expression, and cell surface marker expression in rat thymocytes and splenocytes. Toxicology 135 :49-66. 
Citation: Thakur D, Singh P, Tripathi C, Bhadauria S, Jain SK, et al. (2013) In Vitro Immunotoxicity Testing of Pesticides using Human Cytokine Promoter Based Reporter Cell Lines. Clin Exp Pharmacol S4: 001. doi:10.4172/2161-1459.S4-001

24. Misteli T, Spector DL (1997) Applications of the green fluorescent protein in cell biology and biotechnology. Nat Biotechnol 15: 961-964.

25. Truneh A, Albert F, Golstein P, Schmitt-Verhulst AM (1985) Early steps of lymphocyte activation bypassed by synergy between calcium ionophores and phorbol ester. Nature 313: 318-320.

26. Lee MS, Kim YJ (2007) Signaling pathways downstream of pattern-recognition receptors and their cross talk. Annu Rev Biochem 76: 447-480.

27. Harrison LM, van den Hoogen C, van Haaften WC, Tesh VL (2005) Chemokine expression in the monocytic cell line THP-1 in response to purified shiga toxin 1 and/or lipopolysaccharides. Infect Immun 73: 403-412.

28. Schreiber SL, Crabtree GR (1992) The mechanism of action of cyclosporin A and FK506. Immunol Today 13: 136-142.

29. Andersson J, Nagy S, Groth CG, Andersson U (1992) Effects of FK506 and cyclosporin $A$ on cytokine production studied in vitro at a single-cell level. Immunology 75: 136-142.

30. Sakuma S, Kato Y, Nishigaki F, Sasakawa T, Magari K, et al. (2000) FK506 potently inhibits $\mathrm{T}$ cell activation induced TNF-alpha and IL-1beta production in vitro by human peripheral blood mononuclear cells. $\mathrm{Br} \mathrm{J}$ Pharmacol 130: 1655-1663.

31. Cowgill UM, Gowland RT, Ramirez CA, Fernandez (1991) The history of a chlorpyrifos spill: Cartagena, Colombia. Environ Int 17:61-71.

32. Worthing C, Walker SB (1987) The Pesticide Manual-A World Compendium, seventh ed. British Crop Protection Council, London.

33. van Wijngaarden $R$, Leeuwangh $P$, Lucassen WG, Romijn $K$, Ronday $R$, et al. (1993) Acute toxicity of chlorpyrifos to fish, a newt, and aquatic invertebrates. Bull Environ Contam Toxicol 51: 716-723.
34. Thrasher JD, Madison R, Broughton A (1993) Immunologic abnormalities in humans exposed to chlorpyrifos: preliminary observations. Arch Environ Health 48: 89-93.

35. Voccia I, Blakley B, Brousseau P, Fournier M (1999) Immunotoxicity of pesticides: a review. Toxicol Ind Health 15: 119-132.

36. Sankar P, Telang AG, Manimaran A, Malik JK (2010) Immunoprotective effect of curcumin on cypermethrin-induced toxicity in rats. Toxicological \& Environmental Chemistry 92:1909-1917.

37. Stelzer KJ, Gordon MA (1984) Effects of pyrethroids on lymphocyte mitogenic responsiveness. Res Commun Chem Pathol Pharmacol 46: 137-150.

38. Tamang RK, Jha GJ, Gupta MK, Chauhan HV, Tiwary BK (1988) In vivo immunosuppression by synthetic pyrethroid (cypermethrin) pesticide in mice and goats. Vet Immunol Immunopathol 19: 299-305.

39. Khurana S, Chauhan RS, Mahipal SK (1999) Immunotoxic effects of cypermethrin on delayed type hypersensitivity reaction in chicken. Indian Veterinary Journal 76: 1055-1057.

40. Lafarge-Frayssinet C, Decloître F (1982) Modulatory effect on the pesticide captan on the immune response in rats and mice. J Immunopharmacol 4: 4352.

41. Ullerås E, Trzaska D, Arkusz J, Ringerike T, Adamczewska V, et al. (2005) Development of the "Cell Chip": a new in vitro alternative technique for immunotoxicity testing. Toxicology 206: 245-256.

42. Oostingh GJ, Schmittner M, Ehart AK, Tischler U, Duschl A (2008) A highthroughput screening method based on stably transformed human cells was used to determine the immunotoxic effects of fluoranthene and other PAHs. Toxicol In Vitro 22: 1301-1310.
This article was originally published in a special issue, Novel developments in Immunopharmacology And Immunotoxicology handled by Editor(s). Dr. Gareth E. Davies, South Dakota State University, USA, Anurag Kumar Mishra, Temple University, USA 